\title{
Atrial Natriuretic Polypeptide in the Fetal Rat: Ontogeny and Characterization ${ }^{1}$
}

\author{
LAWRENCE M. DOLAN AND DOUGLAS J. DOBROZSI
}

Division of Endocrinology, Children's Hospital Medical Center, Cincinnati, Ohio 45229

\begin{abstract}
The presence of immunoreactive atrial natriuretic polypeptide (ANP) has been demonstrated in fetal atria early in gestation but further definition of fetal ANP has not been reported. To characterize the principal molecular forms of fetal ANP and to compare fetal ANP to that of the adult of the same species, we extracted the atria of pregnant adult and 20-day fetal rats, the hearts of 14day fetuses, and intact 12-day fetuses in $1 \mathrm{M}$ acetic acid. Tissue collected from littermates was pooled. We measured ANP by radioimmunoassay before and after gel filtration on Sephadex G-75 in each group. ANP concentrations ( $\overline{\mathbf{x}}$ $\pm 1 \mathrm{SD}$ ) in $\mathrm{ng} / \mathrm{mg}$ protein and $\mathrm{ng} / \mathrm{animal}$ were $1296 \pm 505$ and $7707 \pm 1877$ in adult atria $(n=17), 174 \pm 44$ and 62 \pm 13 in 20-day fetal atria $(n=7)$, and $33 \pm 5.3$ and $3.7 \pm$ 0.9 in 14-day fetal hearts $(n=6)$, respectively. Acid extracts from intact 12-day fetuses did not dilute in parallel to the standard curve; therefore, concentrations of ANP for the 12-day fetuses are not reported. ANP concentration rose from the 20 -day fetus to the adult $(p<0.0001)$. The major species of ANP eluting from the Sephadex column had an apparent molecular weight of $16 \mathrm{~K}$ in all groups. We conclude: 1) ANP is present in the fetus shortly after the completion of organogenesis; 2) $16 \mathrm{~K} \mathrm{ANP}$ is the principal intracardiac species in the fetus and the adult; and 3) the existence of ANP soon after cardiac development suggests a possible role for ANP in fetal blood pressure and sodium and water homeostasis. (Pediatr Res 22: 115117, 1987)
\end{abstract}

\section{Abbreviations}

ANP, atrial natriuretic polypeptide

RIA, radioimmunoassay

BSA, bovine serum albumin

ANP, a substance synthesized and secreted by mammalian cardiac atria, has potent natriuretic, diuretic, vasodilatory, and antimineralocorticoid properties (1-7). These characteristics suggest that ANP significantly contributes to sodium homeostasis, water balance, and control of systemic blood pressure $(1,8)$. Three distinct forms of ANP have been documented in adult and immature animals: 1) a $19 \mathrm{~K}$ precursor compound; 2) a 13$15 \mathrm{~K}$ form, the principal intracardiac species; and 3) a $3 \mathrm{~K}$ compound ( $\alpha \mathrm{ANP})$, the major circulating species of ANP (9-

Received July 7, 1986; accepted February 13, 1987.

Correspondence and reprints L. M. Dolan, M.D., Division of Endocrinology, Children's Hospital Medical Center, Elland and Bethesda Avenues, Cincinnati, OH 45229.

Supported by Trustee Research Support Grant Children's Hospital Research Foundation, Cincinnati, $\mathrm{OH}$

'Presented in part at the First World Congress on Biologically Active Atrial Peptides, New York, NY, June 1, 1986.
12). The presence of immunoreactive ANP has been demonstrated in fetal atria early in gestation but further definition of fetal ANP has not been reported (13).

To characterize the principal molecular forms of fetal ANP and to compare fetal ANP to the adult of the same species, we extracted ANP from pregnant adult and fetal (20, 14, and 12 day) Sprague Dawley rats (Harlan, Indianapolis, IN) and measured the concentration of ANP by direct radioimmunoassay before and after gel filtration.

\section{MATERIALS AND METHODS}

Extraction of ANP from tissue. Timed pregnant (20, 14, and 12 day) Sprague Dawley rats were sacrificed by cervical dislocation or decapitation. The hearts of the adult animals and 20-day fetuses were removed and the atria dissected free. The hearts of 14-day fetuses were harvested and processed intact. The 12-day fetuses were removed from the amniotic cavity and handled without further dissection. Atrial tissue from adult animals was processed individually while the fetal tissue of littermates was pooled. All tissue was snap frozen in liquid nitrogen and stored at $-70^{\circ} \mathrm{C}$ until extraction.

While the tissue was still frozen, $2 \mathrm{ml}$ of hot $\left(100^{\circ} \mathrm{C}\right) 1.0 \mathrm{M}$ acetic acid was added to each adult or pooled littermate specimen. The samples were then homogenized for $60 \mathrm{~s}$ (Tissumizer, Tekmar, Cincinnati, $\mathrm{OH}$ ), placed in boiling water for $10 \mathrm{~min}$, cooled on ice, and centrifuged at $30,000 \times g$ for $30 \mathrm{~min}$ at $4^{\circ} \mathrm{C}$. The supernatant was removed, a sample lyophilized for RIA and the remainder stored at $-70^{\circ} \mathrm{C}$ for gel filtration and protein determination. To compare the recovery of immunoreactive ANP among the acid extracts from 14-day fetal hearts and 20day fetal and adult atria, samples from each tissue were homogenized in $1.0 \mathrm{M}$ acetic acid and divided into two equal volumes. One of the samples was spiked with a known concentration of $\alpha$-hANP which was approximately three times the amount of ANP present in the tissue sample. Spiked and unspiked samples were then processed as previously described and the amount of ANP documented by RIA. The recovery of $\alpha$-hANP was calculated by dividing the difference between immunoreactive ANP in the spiked and unspiked samples by the amount of $\alpha$-hANP added to the spiked sample.

Protein concentration was determined by the method of Lowry et al. (14) using a BSA standard (Sigma, St. Louis, MO).

Gel filtration. Acid extracts of adult and 20-day fetal atria, 14day fetal hearts, and 12-day intact fetuses were chromatographed at $4^{\circ} \mathrm{C}$ on a $65 \times 1.6 \mathrm{~cm}$ column of Sephadex G-75, fine grade (Pharmacia, Piscataway, NJ) in $1.0 \mathrm{M}$ acetic acid plus $0.1 \mathrm{mg} /$ ml BSA (Sigma type 7368, St. Louis, MO). One $\mathrm{ml}$ of extract was applied and eluted from the column at $4.5 \mathrm{ml} / \mathrm{h}$ into $1.5-\mathrm{ml}$ fractions. These samples were lyophilized, reconstituted in RIA buffer, and the concentration of ANP determined by direct RIA. The molecular weight of ANP peaks was determined by comparing their elution positions with those of BSA $(66 \mathrm{~K})$, carbonic 
anhydrase $(29 \mathrm{~K})$, cytochrome $\mathrm{C}(12.4 \mathrm{~K})$, aprotinin $(6.5 \mathrm{~K})$, insulin $(6 \mathrm{~K})$, and $\mathrm{ANP}_{8-33}(2.8 \mathrm{~K})$.

$R I A$. Lyophilized tissue extracts and G-75 filtration fractions were reconstituted in RIA buffer $(0.1 \mathrm{M}$ sodium phosphate, 0.05 $\mathrm{M} \mathrm{NaCl}, 0.1 \% \mathrm{BSA}, 0.1 \%$ Triton $\mathrm{X}-100,0.01 \%$ sodium azide, $\mathrm{pH}$ 7.4). RIA was performed using the double antibody method described by Tang et al. (15). The final dilution of ANP antisera was 1:80,000. Rabbit anti-hANP, ${ }^{125} \mathrm{I}$-hANP, $\alpha$-hANP standard, and antirabbit $\gamma$-globulin were obtained from Peninsula Laboratories (Belmont, CA). The cross-reactivity of rabbit anti h-ANP is $100 \%$ with rat ANP (Ile ${ }^{12} \alpha$-hANP), $100 \%$ with rat atriopeptin III, $5 \%$ with rat atriopeptin II, and $0 \%$ with rat atriopeptin I. The sensitivity of the assay in our laboratory is $4 \mathrm{pg} / \mathrm{tube}$. At $50 \%$ displacement our intraassay coefficient of variation is $4.1 \%$ $(n=7)$ and our interassay coefficient of variation is $10 \%(n=$ 6).

Due to the technical difficulty of isolating atria from 14- and 12-day-old fetuses, fetal hearts (14 day) and whole fetuses (12 day) were used for extraction. All samples diluted in parallel to the standard curve of the RIA except for those obtained prior to gel filtration from the 12-day fetuses (Fig. 1). As a result concentrations of ANP in the 12-day fetus are not reported. ANP concentrations are expressed per mg protein and per animal. However, due to a different source of ANP (atrial in adult and 20-day fetus and whole heart in 14-day fetus), statistical analysis was only performed on adult and 20-day specimens. The mean concentration of ANP in the fetal samples was calculated using a value weighted according to litter size. An analysis of variance was employed to compare 20-day fetal and maternal values with fetal samples weighted according to litter size and maternal sample given a weight of one (16).

\section{RESULTS}

The recovery of ANP in acid extracts from 14-day fetal hearts and 20-day fetal and adult atria were 98.8 $\pm 6.0,83.3 \pm 23.2$, and $117 \pm 10.0 \%(\overline{\mathrm{x}} \pm 1 \mathrm{SD}, n=3)$, respectively. Reported concentrations of immunoreactive ANP are corrected for recovery of $\alpha$-hANP when the recovery was less than $100 \%$.

The concentrations of immunoreactive ANP $(\bar{x} \pm 1$ SD) are depicted in table 1 . The concentration of ANP immunoreactivity increased from the 20-day fetus to the adult whether expressed as $\mathrm{ng} / \mathrm{mg}$ of protein or $\mathrm{ng}$ per animal $(p<0.0001)$.

The gel filtration experiments documented that the molecular weight species of immunoreactive ANP in the extracts of adult and 20- and 14-day fetuses were identical (Fig. 2). Furthermore,

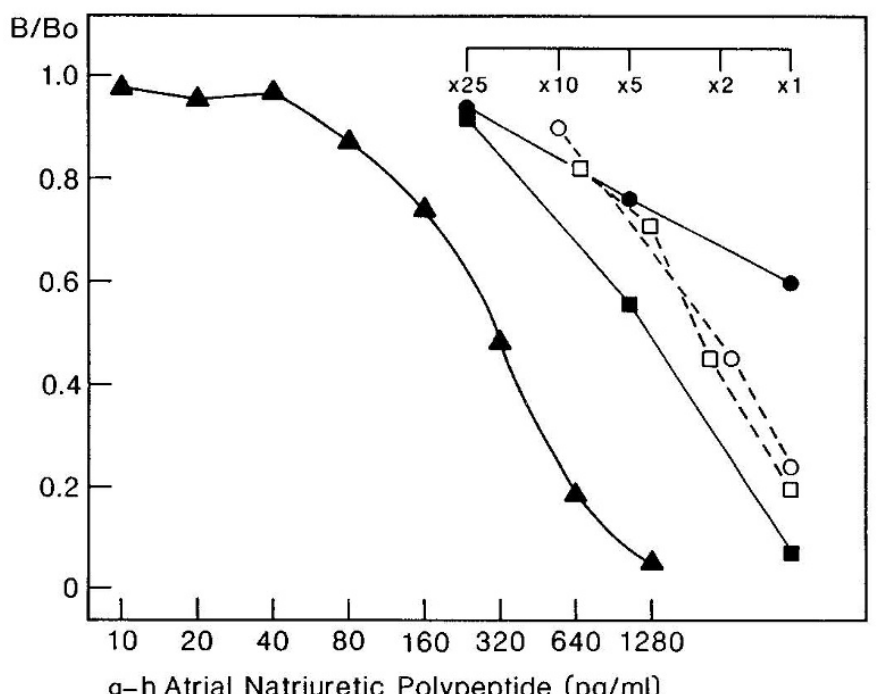

Fig. 1. Dilution curve of $\boldsymbol{\Delta}, \alpha$-h atrial natriuretic polypeptide (standard curve); $\square$, adult atrial extract; $\square, 20$-day fetal atrial extract; $O, 14$ day fetal heart extract; and $\bullet$, 12-day whole fetal extract.
Table 1. Concentration of immunoreactive ANP*

\begin{tabular}{lcc}
\hline \multicolumn{1}{c}{ Age $(n)$} & ng/mg protein & ng/animal \\
\hline Adult (17) & $1296 \pm 505 \dagger$ & $7707 \pm 1877 \dagger$ \\
20-day fetal $\ddagger$ (7) & $174 \pm 44$ & $62 \pm 13$ \\
14-day fetal $(6)$ & $33 \pm 5.3$ & $3.7 \pm 0.9$ \\
\hline
\end{tabular}

* ANP immunoreactivity $(\bar{x} \pm 1 \mathrm{SD})$ in adult and 20 -day fetal atria and 14-day fetal hearts.

$\dagger$ Different than 20-day fetus $(p<0.0001)$.

$\ddagger$ Pooled littermates.

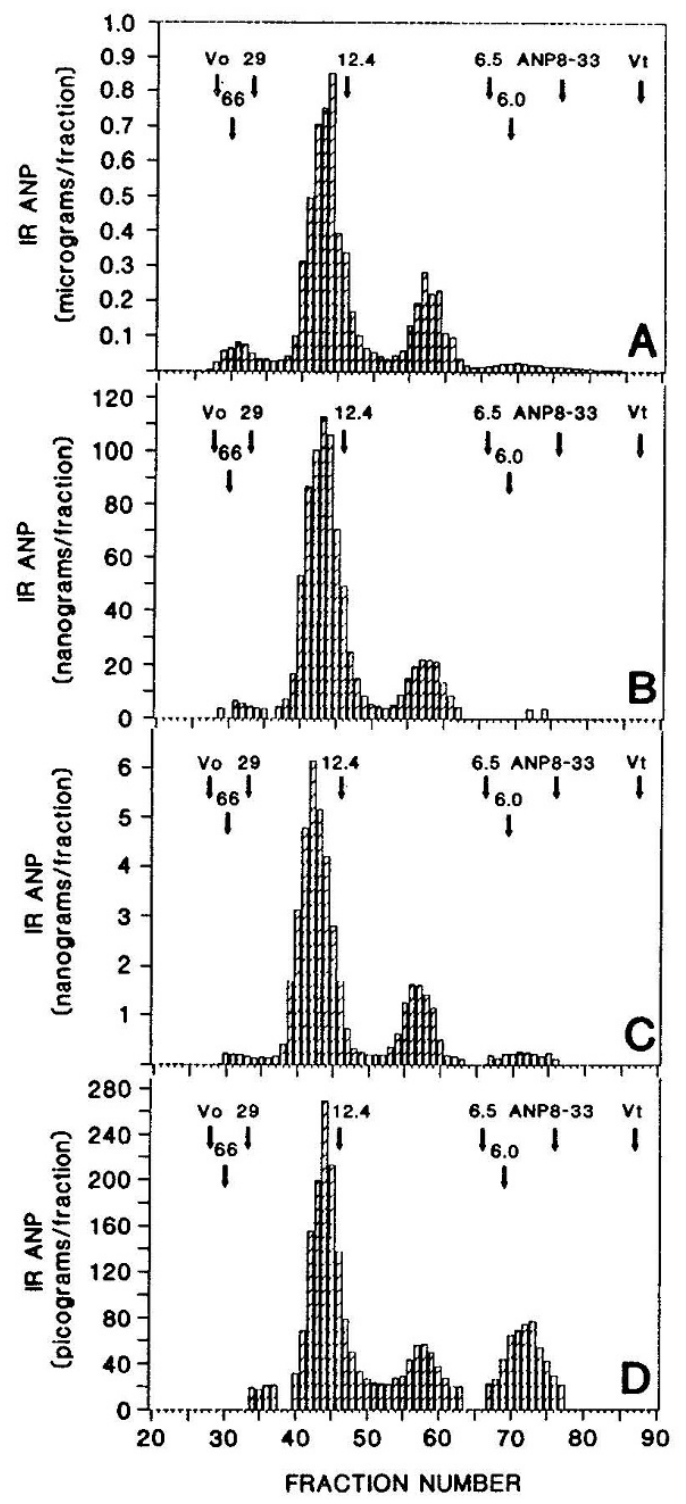

Fig. 2. Immunoreactive atrial natriuretic polypeptide concentration in gel filtration fractions from maternal atria $(A), 20$-day fetal atria $(B)$, 14-day fetal hearts $(C)$, and 12-day whole fetuses $(D)$.

the principal species of ANP in all age groups has an approximate molecular weight of $16 \mathrm{~K}$. A second peak of immunoreactivity was identified in all age groups with an approximate molecular weight of $9 \mathrm{~K}$. Finally, a peak of immunoreactive ANP corresponding with 3-6 K ANP was identified in the 12-day-old fetuses.

\section{DISCUSSION}

These data document the presence of immunoreactive ANP in the fetus shortly after the completion of organogenesis. In 
addition, the principal intracardiac species of ANP in the adult and 20- and 14-day-old fetus has an apparent molecular weight of $16 \mathrm{~K}$. These results are in agreement with previous reports (911) using adult rat and human atria which suggested that the principal intraatrial species has a molecular weight of 13-15 K. The chromatogram from the 12-day fetus also documents a predominance of $16 \mathrm{~K} \mathrm{ANP}$. The use of intact fetuses prevents localization of the source of $16 \mathrm{~K}$ ANP. However, no study has documented an extraatrial orgin for high molecular forms of ANP suggesting that the source of $16 \mathrm{~K} \mathrm{ANP}$ in the 12-day fetus is also the atrium.

A second peak of immunoreactive ANP was identified in all ages with an apparent molecular weight of $9 \mathrm{~K}$. These data are in agreement with other studies $(17,18)$ which also identified 9 $\mathrm{K}$ immunoreactive ANP in atrial extract. While the significance of this form of ANP remains to be determined, potential explanations of this finding include the possibility that $9 \mathrm{~K} \mathrm{ANP}$ is a degradation product of precursor ANP induced by our experimental design and has no physiological significance; that $9 \mathrm{~K}$ ANP is a trimer of $\alpha \mathrm{ANP}$; and that $9 \mathrm{~K} \mathrm{ANP}$ is an intermediate form of ANP in the processing of the precursor compound to the circulating form of ANP.

A third immunoreactive peak of ANP with an apparent molecular weight of 3-6 K was identified only in the extract of 12day, intact fetuses. The significance of this peak is unclear. It may be the result of proteolytic digestion of $16 \mathrm{~K}$ ANP by proteases in the fetal homogenate. However, the reports of a $5 \mathrm{~K}$ antiparallel dimer of $\alpha$ ANP (19) and the presence of $3 \mathrm{~K}$ ANP in both fetal hematopoetic tissue of the liver (20) and fetal hypothalamic cells (21) suggest that this peak may also represent either $5 \mathrm{~K}$ ANP or $\alpha$ ANP extracted from the blood or target organs in the fetus.

In summary the data presented document the presence of immunoreactive ANP in the fetus shortly after organogenesis. The concentration of intraatrial ANP increased from the 20-day fetus to the adult. The principal ANP species in all ages studied has a molecular weight of $16 \mathrm{~K}$. The existence of ANP soon after cardiac development suggests a possible role for ANP in fetal blood pressure and sodium and water homeostasis.

Acknowledgments. The authors thank Ms. Diane Witson and Judy Moermond for their excellent technical assistance in preparing this manuscript.

\section{REFERENCES}

1. Ballerman BJ, Brenner BM 1985 Biologically active atrial peptides. J Clin Invest 76:2041-2048
2. Chapeau C, Gutkowska J, Schiller PW, Milne RW, Thibault G, Garcia R, Genest J, Cantin M 1985 Localization of immunoreactive synthetic atrial natriuretic factor (ANF) in the heart of various animal species. $J$ Histochem Cytochem 33:541-550

3. Weidman P, Hasler L, Gnadinger MP, Lang RE, Uehlinger DE, Shaw S, Rascher W, Reubi F 1986 Blood levels and renal effects of atrial natriuretic peptide in normal man. J Clin Invest 77:734-742

4. Kihara M, Nahayama K, Nakao K, Sugawara A, Morii N, Sakamoto M, Suda M, Shinokura M, Kiso Y, Imura H, Yamori Y 1985 Accelerated natriuresis induced by synthetic atrial natriuretic polypeptide in spontaneous hypertensive rats. Clin Exp Hypertens [A]7:539-551

5. Kleinert HD 1984 Atrial natriuretic factor inhibits angiotensin, norepinephrine and potassium-induced vascular contractibility. Hypertension 6:1143-147

6. Yasugima M, Abe K, Kohzuki M, Manno M, Kasai Y, Sato M, Omata K, Kudo K, Tsunoda K, Takeuchi K, Yoshinaga K, Inagama T 1985 Atrial natriuretic factor inhibits hypertension induced by chronic infusion of norepinephrine in conscious rats. Circ Res 57:470-474

7. Kudo T, Baird A 1984 Inhibition of aldosterone production in the adrenal glomerulosa by atrial natriuretic factor. Nature 312:756-757

8. Dillingham MA, Anderson RJ 1986 Inhibition of vasopressin action by atrial natriuretic factor. Science 231:1572-1573

9. Bloch KD, Scott JA, Zisfein JB, Fallon JT, Margolies MN, Seidman CE Matsueda GR, Homcy CJ, Grahman RM, Seidman JG 1985 Biosynthesis and secretion of proatrial natriuretic factor by cultured rat cardiocytes. Science 230:1168-1171

10. Miyata A, Kangawa K, Toshimori T, Hatch T, Matsuo H 1985 Molecular forms of atrial natriuretic polypeptides in mammalian tissues and plasma. Biochem Biophys Res Commun 129:248-255

11. Vuolteenaho O, Arjamaa O, Ling N 1985 Atrial natriuretic polypeptides (ANP): rat atria store high molecular weight precursor but secrete processed peptides of 25-35 amino acids. Biochem Biophys Res Commun 129:82-88

12. Thibault G, Lazure C, Schiffrin EL, Gutkowska J, Chartier L, Garcia R, Seidah NG, Chretien M, Genest J, Cantin M 1985 Identification of a biologically active circulating form of rat atrial natriuretic factor. Biochem Biophys Res Commun 130:981-986

13. Morinaga S. Taumuraya M, Nakajima T, Shimosato $Y$, Yoshinaga K, Yamaguchi K. Abe K, Ohno H, Kanai A 1985 Immunohistochemical and immunocytochemical location of atrial natriuretic polypeptide in human adult and fetal hearts. Acta Histochem Cytochem 18:605-613

14. Lowry OH, Rosebrough NJ, Fan AL, Randall RJ 1951 Protein measurement with the folin phenol reagent. J Biol Chem 193:265-275

15. Tang J, Fei H, Xie CW, Suen MZ, Han JS 1984 Characterization and localization of atriopeptin in rat atrium. Peptides 5:1173-1177

16. Winer BJ 1971 Statistical Principles in Experimental Design. McGraw-Hill, New York, pp 417-419

17. Cantin M, Genest J 1985 The heart and the atrial natriuretic factor. Endocr Rev 6:107-127

18. Davies PL, de Bold AJ, deBold ML, Flynn TG. Kennedy B 1985 Main forms of immunoreactive natriuretic factor in atrial tissue and in isolated special atrial granules. Proc Can Fed Biol Soc 28:164(abstr)

19. Kangawa K, Fukuda A, Minamino N, Matsuo H 1984 Purification and complete amino acid sequence of beta-rat atrial natriuretic polypeptide ( $\beta$ rANP) of 5000 daltons. Biochem Biophys Res Comm 119:933-940

20. Currie MG, Simson JAV, Thompson RP 1986 Evidence for atrial peptide localization in hematopoietic cells. J Cardiovasc Pharmacol 8:1329

21. Morgan K, Lewis M, Scanlon MF, Mir MA 1986 Fetal rat hypothalamic cells release a sodium transport inhibitor, a pro-inhibitor and atrial natriuretic peptide. J Cardiovasc Pharmacol 8:1331 